\title{
Electoral Uncertainty and Corporate Investment: Evidence from European Countries
}

\author{
Michal MÁDR*
}

\begin{abstract}
The aim of the paper is to identify whether electoral uncertainty affects corporate investment, which may cause cyclical fluctuations in European countries. More specifically, the paper focuses on the development of a net fixed-asset investment from 2006 to 2015. Electoral uncertainty is associated with the parliamentary election term since this is the most common election type. The paper is focused on 268,000 firms within the secondary sector (NACE Rev. 2 Sections C-F; Amadeus database). The results suggest that electoral uncertainty may have a negative impact on investment in the secondary sector. Comparing individual industries shows that the negative impact may occur in the construction industry, whereas the effect is statistically inconclusive in the case of manufacturing. Considering the size of the enterprises, electoral uncertainty has a greater impact on SMEs, generally in the secondary sector and, more specifically, in construction. Extending the topic of the economic consequences of the political cycle, including the impact of electoral uncertainty on corporate investment across sectors and business sizes, can be considered as the main contribution of the article.
\end{abstract}

Keywords: Electoral uncertainty, corporate investment, secondary sector, SMEs and large companies

JEL Classification: E32, G31, P16

DOI: https://doi.org/10.31577/ekoncas.2021.06.05

\section{Introduction}

An investment is the most volatile component of the GDP, especially within the European area, because investment expenditures are much more volatile than in the case of the US economy (Kolev, Brutscher and Weiss, 2016). Economic

\footnotetext{
* Michal MÁDR, Mendel University in Brno, Faculty of Business and Economics, Department of Economics, Zemědělská 1665/1, 61300 Brno, Czech Republic; e-mail: xmadr@mendelu.cz
} 
theory has dealt with the causes of these fluctuations for at least one hundred years or more. Nevertheless, there are explanations of investment fluctuations that have not yet been sufficiently tested. More specifically, the issue of political uncertainty, in particular the issue of electoral uncertainty, is such a case. Although earlier empirical literature was focused on aggregate corporate investment, recently the emphasis has been placed on empirical testing at the corporate level. By using the Amadeus database, vast amounts of companies of all sizes can be analysed.

The paper is focused on EU member states because despite institutional differences there are common business conditions that allow a better analysis of the effects of electoral uncertainty. The issue is explored within the secondary sector in which irreversible investment expenditures are typical. The secondary sector includes four industries: manufacturing (NACE Rev. 2 Sections C); electricity, gas, steam and air conditioning supply (Section D); water supply, sewerage, waste management and remediation activities (Section E) and construction (Section F). Irreversible investment means that the capital which was once installed has little or no value unless used in production, and it is specifically the irreversible investment that is linked to the issue of (electoral) uncertainty since uncertainty leads to the postponement of investment expenditures. Simultaneously, the secondary sector is an important part of the European economy since it generates approximately $22 \%$ of the total gross value added, and it employs about forty million people (Eurostat, 2017).

The aim of the paper is to verify whether electoral uncertainty affects corporate investment in European countries. The literature review provides a survey of the current theoretical and empirical background. The used proxies, regression methods and a sample of the observed countries are described in the methodology section. The results section is divided into two parts. First, the impact of electoral uncertainty within the secondary sector is observed, and subsequently the influence in differently sized enterprises is analysed. The conclusion summarises the major findings.

\section{Literature Review}

The following section summarises the knowledge in the theoretical and empirical literature that deals with the influence of uncertainty on corporate investment. First, the basic issue is briefly introduced, followed by the issue of policy uncertainty and then by the summary of the findings regarding the influence of electoral uncertainty on corporate investment.

At the most general level, the paper deals with the issue of investment fluctuations. The literature offers a multitude of explanations regarding why these 
fluctuations occur. The paper is based on the 'irreversible' investment, which means that if individual investment projects were 'once constructed, they cannot be undone or made into a radically different type of projects without high costs' (Bernanke, 1983, p. 86). Additionally, Bernanke (1983, p. 86) states that 'new information relevant to assessing long-run project returns arrives over time; so that, by waiting, the potential investor can improve his chances of making a correct decision'. These two assumptions lead to the fact that 'when individual projects are irreversible, agents must make investment timing decisions that trade off the extra returns from early commitment against the benefits of increased information gained by waiting' (Bernanke, 1983, p. 85). In other words, uncertainty can create investment fluctuations since temporarily increases the yield of waiting for information.

The previous paragraph can be summed up through two articles by Carruth, Dickerson and Henley (2000) and Koetse, de Groot and Florax (2009). Carruth, Dickerson and Henley (2000) analysed seventeen papers addressing the issue both at the aggregate and corporate levels. Their conclusion was that the predicted negative influence prevails in empirical literature. In the second case (Koetse, de Groot and Florax, 2009), the results of the meta-analysis for thirty-six articles from 1989 to 2005 suggest that the negative effect was in $66 \%$ of cases, and the positive effect was in $34 \%$. On the other hand, if statistical significance is considered, then the anticipated negative effect was significant in $30 \%$ of the cases, while positive only in $4 \%$. Moreover, both the articles state that a summary of the effect of uncertainty on investment is ambiguous because thematic literature has identified a large number of sources of uncertainty both at microeconomic (e.g. volatility in demand, in market share, in sales and in profit) and macroeconomic (e.g. volatility in exchange rates, in inflation, in stock market returns, in political environment and in economic policy) levels.

When focusing on the development of the investigation of the effect of uncertainty on business investment, it is possible to see that the interest in empirical literature shifts to political and policy uncertainty within macroeconomic causes of uncertainty. Therefore, the paper focuses specifically on the issue of electoral uncertainty. These two types of macroeconomic instability are described in more detail because electoral uncertainty is part of political uncertainty and is simultaneously linked to policy uncertainty.

Policy uncertainty can be defined as uncertainty about a monetary or fiscal policy or a regulatory regime. According to Stokey (2016, p. 257), during a financial crisis, the private sector can wait for a reaction from the economic policymakers and thus delay investment expenditures. If fiscal or monetary incentives prove to be ineffective, then the planned investments will be postponed 
again. The postponement of corporate investment leads to greater fluctuations in the economic cycle and increases the time needed for economic recovery in times of crisis.

According to Muntaz and Surico (2018), policy uncertainty explains up to $25 \%$ of the fluctuations in US economic output over the last forty years. Also, Higgs $(1997)^{1}$ demonstrates the finding using the example of the slow recovery of the US economy during the Great Depression. Policy uncertainty also has one major consequence as the stability and credibility of economic policy is more important than the setting amount of individual tax or interest rates; thus, a discretionary economic policy may not be effective, especially in the period of long-term economic instability or uncertainty (Pindyck, 1991, p. 1141).

According to Gulen and Ion (2015, p. 561 - 562), restoring an original investment level in the US economy takes two to three years after the initial shock. Policy uncertainty also affects stock market volatility (Liu and Zhang, 2015) and stock market returns (Arouri et al., 2016; Kang and Ratti, 2013), especially in the case of oil shocks (Kang and Ratti, 2013) or during a period of long-term volatility (Arouri et al., 2016).

The question of political uncertainty is linked to electoral uncertainty in most empirical contributions, as well as in this paper. Within the individual articles, Julio and Yook (2012) can be considered a pivotal article. According to these authors, corporate investment rates decline by an average of $4.8 \%$ in the period leading up to elections. The authors explain that elections can lead to a change of government (ruling party), so there is a risk of significant changes in the implementation of the economic policy after the elections.

The influence of electoral uncertainty on individual types of investment can be found in Marcelin et al. (2019), who monitored the impact of elections (parliamentary and presidential) on fixed and intangible assets. These authors conclude that a fixed-asset investment is influenced by the presidential elections, especially when the elections are held jointly with parliamentary elections, whereas an intangible asset investment is affected only by parliamentary elections. The empirical literature also researched the influence of electoral uncertainty in individual countries, namely in Australia (Narayan, Narayan and Tran, 2017), Germany (Riem, 2016), Italy (Amore and Minichilli, 2018), Spain (Dejuán and Ghirelli, 2018) and the United States (Jens, 2017). The mentioned authors emphasised the analysis of parliamentary and regional elections. The authors (excluding Narayan, Narayan and Tran, 2017) agree on the negative impact of electoral uncertainty.

\footnotetext{
${ }^{1}$ Note that Higgs (1997) does not use the term 'policy uncertainty' but 'regime uncertainty'. This tiny nuance is not important in this paper.
} 
In the conclusion of the section, it should be mentioned that although interest in the impact of electoral uncertainty on investment expenditures has been growing in recent years, there are still areas which have not been sufficiently processed. And the article focuses on one of these areas. Namely, it is a comparison across economic sectors and different sized companies.

\section{Methodology}

The following section describes the individual proxies, regression models with fixed effects, the sample of selected countries and the classification of enterprises according to their size.

The individual proxies can be divided into three groups: the firm-level data, the macroeconomic control variables and the electoral indicators. The firm data is obtained from the Amadeus database (Van Dijk, 2019); the macroeconomic control variables are acquired from the Eurostat database (Eurostat, 2019); and the electoral dummies are obtained from the ParlGov database (Döring and Manow, 2020).

The article focuses on corporate investment, namely an investment in net fixed assets (NFA), which means that fixed assets are reduced by depreciation. In accordance with Jens (2017) and Marcelin et al. (2019), the proxy is expressed as a share of fixed assets in the total assets, which allows comparability across different-sized firms. ${ }^{2}$

In the empirical literature, there is no single list of suitable control variables at the corporate level (see Koetse, de Groot and Florax, 2009). Also, data availability varies considerably across different variables. For these reasons, six control proxies are selected, namely the Size, ROA, ShortDebtRatio, LongDebtRatio, CashFlowAssets and Liquidity.

Proxy Size means the size of the firm measured as the natural logarithm of the total assets. ROA means the return on the total assets expressed as the share of the EBIT in the total assets; ShortDebtRatio means the share of the current liabilities in the total assets; LongDebtRatio means the share of the long-term liabilities in the total assets; CashFlowAssets means the share of the cash flow in the total assets; and Liquidity is measured as the current assets minus the inventories divided by the current liabilities. The positive effect is assumed for three

\footnotetext{
${ }^{2}$ Of course, many other expressions of investment expenditure appear in the empirical literature (see Koetse, de Groot and Florax, 2009). The two most commonly used variables, the share of investment in sales and the total capital expenditure, are not employed since in the first case, the data is not available for some states, while in the latter case, other types of investment expenditure are not available for a significant proportion of the monitored companies.
} 
variables (Size, ROA, CashFlowAssets), whereas the ambiguous effect is expected in the case of the other control proxies (ShortDebtRatio, LongDebtRatio, Liquidity; for more, see Kajurová and Linnertová, 2018).

The mentioned authors (e.g. Gulen and Ion, 2015; Julio and Yook, 2012; Marcelin et al., 2019) also used Tobin's Q, which is not included, since the indicator is not applicable to the observed sample of companies. Also, the variable size of sales (e.g. Bloom, Bond and Van Reenen, 2007; Gulen and Ion, 2015; Marcelin et al., 2019) is not employed because the data is not available for some countries (e.g. Ireland and United Kingdom). In addition, some authors (e.g. An et al., 2016; Kajurová and Linnertová, 2018; Kang, Lee and Ratti, 2014) include lagged dependent proxy in the regression model. The inclusion is not appropriate since it can lead to biased results in the case of the OLS with fixed effects (see Nickell, 1981).

Two macroeconomic proxies are employed in the paper, Growth and Debt. The percentage change in the real GDP per capita in the previous year (Growth; Eurostat, 2019) is used since the variable expresses the effect of the economic cycle on the investment decision (e.g. Julio and Yook, 2012; Marcelin et al., 2019). Simultaneously, the variable is delayed by one year due to a possible endogenous relationship between investment expenditures and economic performance. A positive influence is expected. Second, the government consolidated gross debt to GDP (Debt; Eurostat, 2019) represents the macroeconomic stability in the context of the recent financial crisis. In general, a higher level of government debt should lead to lower investment expenditures, both through higher (macroeconomic) uncertainty and due to the crowding-out effect.

The dummy variable Elect is the most employed variable within the empirical literature examining the impact of electoral uncertainty or political budget cycle. The proxy is used to express the year in which parliamentary or presidential elections take place. The paper only works with the parliamentary elections, because the purely presidential system does not occur within the EU countries and there are only several countries with a semi-presidential system (France, Lithuania, Poland, Portugal and Romania). Moreover, in these five states the parliament has an important position within political system, therefore focusing only on the parliamentary elections can be considered as relevant.

In accordance with Julio and Yook (2012, p. $80-81)$, the issue of electoral uncertainty is extended by two variables, ElectDate and PostElect. ElectDate is a dummy variable code 1 if the date of the election lies between 90 days prior to the end of the fiscal year $t$ and 274 days after the end of the fiscal year $t$. However, PostElect is a dummy variable code 1 if the date of the election lies between 274 days before the beginning of the fiscal year $t$ and 90 days after the beginning of the fiscal year $\mathrm{t}^{3}$ 
The variables have the advantage that they take the election date into account; thus, they can better express uncertainty in making investment-spending decisions. More specifically, the variable ElectDate is based on the idea that if elections take place in the first half of the year, then they influence the decisionmaking of the actors in the previous year, whereas in the case of PostElect, if elections are held in the second half of the year, then they can influence the decision-making regarding the investment in the following year.

The individual variables and their description are presented in the Appendix (see Table A1).

Panel data regression analysis is the main instrument. There are two basic methods in the panel data: the fixed and random effects. The Hausman test was chosen to determine the suitable method (random effects are preferred under null hypothesis, while the preference for fixed effects is an alternative hypothesis). Econometric verification is carried out by testing the occurrences of homoscedasticity (the Wald test) and serial autocorrelation (the Wooldridge test). The fixed-effects method is chosen according to the result of the Hausman test. ${ }^{4}$ The fixed-effects model incorporates heteroscedasticity and serial autocorrelation. If cross-sectional units are more than the time series units, then a cluster option is a suitable instrument, see Hoechle (2007). The estimated regression coefficients remain the same, and heteroscedasticity and serial autocorrelation also persist in the model, but the standard errors are calculated as being robust. One can then consider the estimated regression coefficients to be efficient. As the cluster option, individual countries are used since there is an assumption that the investment activity of companies is influenced by the state in which these companies operate (Julio and Yook, 2012). The possibilities of using individual cluster conditions are described by Petersen (2009). Also, each regression contains the year and the firm fixed effects. The selected models with the fixed effects can be expressed by the following equations:

$$
\begin{aligned}
& N F A_{i j t}=\beta_{0}+\beta_{k} \sum\left(\text { Firm }_{i j t}+\beta_{k} \sum\left(\text { State }_{j t-1}+\beta_{9} \text { ElectProxies }_{j t}+\right.\right. \\
& +\varphi_{i}+\omega_{t}+\varepsilon_{i j t}
\end{aligned}
$$

\footnotetext{
${ }^{3}$ The authors for the proxy ElectDate used 60 days before the end of the fiscal year $\left(1^{\text {st }}\right.$ November) as the starting date, but in the case, there is a problem with the inclusion of elections in October because $1^{\text {st }}$ October $\left(274^{\text {th }}\right.$ day $)$ is the last date in the following fiscal year. For this reason, 90 days before the end of the fiscal year is considered the starting date in this paper. The same change was also made for the second variable. In the investigated group of countries, the fiscal year is the same as the calendar year, except for the United Kingdom, where the fiscal year starts on $1^{\text {st }}$ April and ends on $31^{\text {st }}$ March.

${ }^{4}$ A null hypothesis regarding the preference of random effects in favour of the alternative hypothesis regarding the preference of the fixed effects is rejected. A Chi-square is 74986.87 (p-value 0.00).
} 


$$
\begin{aligned}
& N F A_{i j t}=\beta_{0}+\beta_{k} \sum\left(\text { Firm }_{i j t}+\beta_{k} \sum\left(\text { State }_{j t-1}+\beta_{9} \text { Elect }_{j t}+\beta_{10} \text { PostElect }_{j t}+\right.\right. \\
& +\varphi_{i}+\omega_{t}+\varepsilon_{i j t}
\end{aligned}
$$

where $i$ indexes the firm, $j$ the country, and $t$ denotes the year. $N F A_{i j t}$ is the net fixed investment measured as a share of the net fixed assets in the total assets;

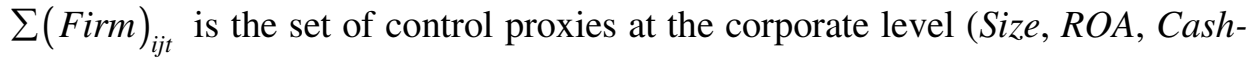
FlowAssets, ShortDebtRatio, LongDebtRatio, LiquidityRatio); $\sum(\text { State })_{j t-1}$ is the set of control proxies at the state level (Growth, Debt); ElectProxies ${ }_{j t}$ represents the individual election proxies (Elect and ElectDate), which are tested separately; $\varphi_{i}$ captures the firm fixed effects; $\omega_{t}$ captures the year fixed effects; and $\varepsilon_{i j t}$ is an unobserved error term. The employed proxies are described in Table A1 (Appendix).

The paper is focused on EU countries. Because of the shortage of suitable firm data, seven EU member states are not included (Cyprus, Denmark, Lithuania, Latvia, Luxembourg, Malta and the Netherlands). The data (fixed assets) is not available for Cyprus, Luxemburg and Malta within the researched period, whereas in the case of Denmark, the data (fixed assets) is available only from 2011 to 2015. Latvia, Lithuania and the Netherlands were excluded due to the low number of companies (limited data availability for cash flow and depreciation).

The influence of election uncertainty on firm investment is researched within the secondary sector, which means NACE Rev. 2 Sections C (manufacturing), D (electricity, gas, steam and air conditioning supply), E (water supply, sewerage, waste management and remediation activities) and $\mathrm{F}$ (construction). The Amadeus database contains data for about 1.7 million companies in the secondary sector. After making the necessary adjustments (e.g. removing companies with missing or meaningless values, omitting countries with a low number of observations), the paper uses the data for about 268,000 firms. This amount represents approximately $10 \%$ of all the companies operating in the secondary sector (Eurostat, 2017).

This sector has been chosen for three reasons. First, it can be assumed that irreversible investment expenditures are typical for the sector (Bloom, Bond and Van Reenen, 2007). Second, the sector generates about $22 \%$ of the total gross value added and employs about forty million people (Eurostat, 2017). Third, the manufacturing industry, as the most import aspect of the secondary sector, is the most frequently analysed sector within the thematic literature (e.g. Bloom, Bond and Van Reenen, 2007; Kang, Lee and Ratti, 2014; Riem, 2016).

Furthermore, the influence of electoral uncertainty is extended by the question of whether the impact of this uncertainty is the same in different-sized businesses. The paper uses basic division, so it is distinguished between SMEs and large 
enterprises. The number of employees is used as an assessment criterion, which means that if the enterprise has less than 249 employees, it is classified as an SME, while if it has 250 employees and more, it is classified as a large enterprise. The number of firms, for each country and NACE sector, is presented in Table 1.

Table 1

Number of Firms across Countries and NACE Sectors

\begin{tabular}{|l|r|l|r|l|r|}
\hline Country & Firms & Country & Firms & Country & \multicolumn{1}{c|}{ Firms } \\
\hline Austria & 1,218 & Finland & 6,953 & Portugal & 1,309 \\
Belgium & 34,815 & France & 50,045 & Romania & 19,830 \\
Bulgaria & 2,285 & Greece & 2,121 & Sweden & 1,772 \\
Croatia & 6,252 & Hungary & 7,196 & Slovakia & 3,031 \\
Czech Republic & 6,486 & Ireland & 895 & Slovenia & 2,300 \\
Germany & 9,232 & Italy & 83,030 & Spain & 4,317 \\
Estonia & 2,467 & Poland & 4,551 & United Kingdom & 17,515 \\
\hline NACE & Firms & NACE & Firms & NACE & Firms \\
\hline C & 149,062 & D-E & 10,474 & F & 108,084 \\
\hline Total & & & & & $\mathbf{2 6 7 , 6 2 0}$ \\
\hline
\end{tabular}

Source: Own calculations based on data from Van Dijk (2019).

\section{Results}

The section is divided into two parts. First, the influence of electoral uncertainty on corporate investment in the secondary sector is analysed. The effect is then investigated in the SMEs and large companies.

The influence of electoral uncertainty is presented via Figure 1 in which the average values of the net fixed investment to total assets in the secondary sector according to the individual years of the political cycle are depicted. The election year is expressed by three variables, Elect (1 for election year), ElectDate ( 1 if the election date is between 90 days prior to the end of the fiscal year $t$ and 274 days after the end of the fiscal year $\mathrm{t}$ ) and PostElect ( 1 if the date of the election lies between 274 days before the beginning of the fiscal year $t$ and 90 days after the beginning of the fiscal year $t$ ). The other years of the political cycle are derived from the expression of the election year.

The graph shows two findings. First, the level of the net fixed investment is higher in the years after than in the years before parliamentary elections (Elect and ElectDate). Second, in the first two cases, the lowest level of the net fixed investment occurs in the election year and one year before the elections, whereas the post-electoral effect proves to be effective after the election years. The finding may indicate that if elections are held in the first half of the year, they would have had an impact on investment decisions in the previous year, while elections in the second half of the year tend to affect investment decisions for the next year. 
Fig u r e 1

Net Fixed Assets to Total Assets in Secondary Sector around National Elections

( $\mathrm{t}$ is election year)

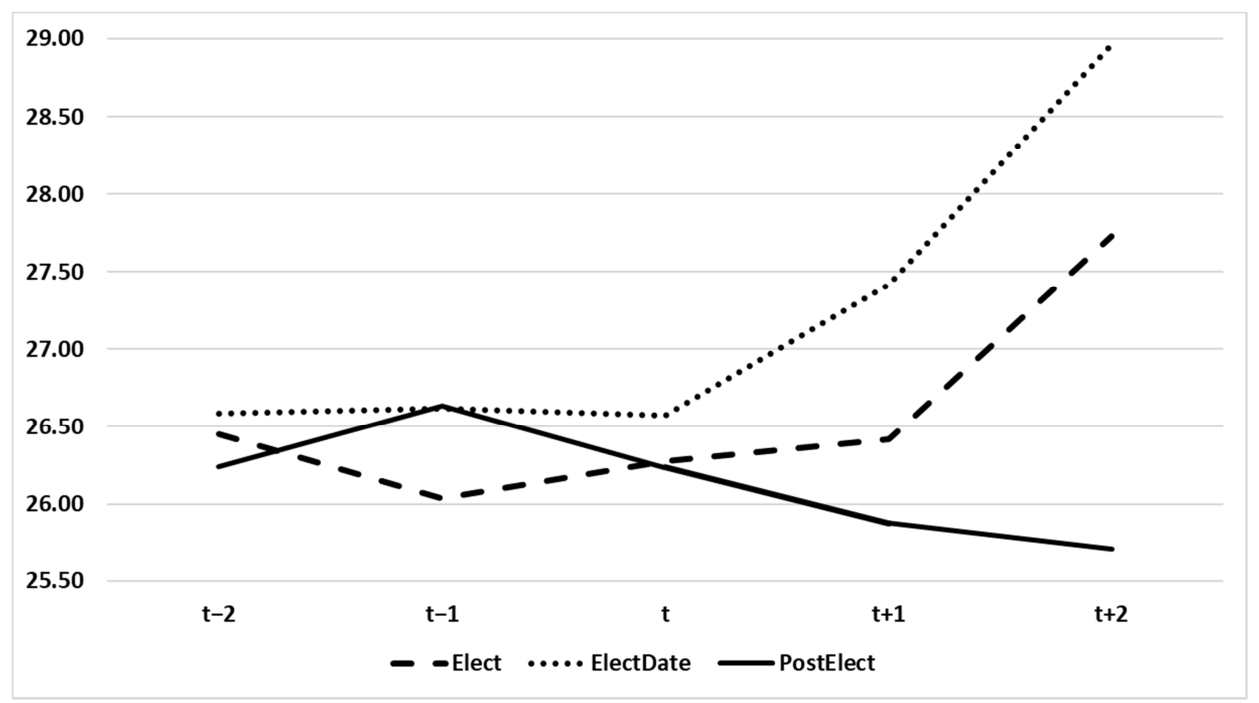

Source: Own calculations based on data from Döring and Manow (2020) and Van Dijk (2019).

\section{The Electoral Uncertainty and Corporate Investment in European Countries}

In the first part, the impact of electoral uncertainty on the secondary sector is monitored. The results for the secondary sector, manufacturing and construction industry are presented in Table 2, whereas the outputs for the water and electricity supply are stated in Table A2 (Appendix). The sector is represented by 268,000 companies. Based on the results of the control variables, it is possible to state that the firm's investment in net fixed assets depends on the size of the company and the short-term debt (Jens, 2017; Marcelin et al., 2019) and also on the liquidity ratio (Kajurová and Linnertová, 2018) in the case of electricity, the water supply and construction. On the other hand, macroeconomic control proxies (Growth and Debt) seem to be insignificant, except for in the construction industry (Growth).

The results for the election proxies indicate that the negative effect of holding parliamentary elections on corporate investment in the secondary sector can be statistically significant. Looking more closely, the negative effects may be manifested in the election year, and there may also be post-electoral influence. This means that the level of the net fixed assets to total assets in the election year is about 0.4 lower compared to the non-electoral years (at an average level of 
26.17\%). In other words, the net fixed investment declines by about $1.9 \%$ in the election year. The basic finding corresponds with the empirical literature according to which the influence of electoral uncertainty (without conditional effects) ranges from $0.35 \%$ (Amore and Minichilli, 2018) to over $1.62 \%$ (Narayan, Narayan and Tran, 2017), 2.3\% (Marcelin et al., 2019) and 4.8\% (Julio and Yook, 2012) to $10.5 \%$ (Riem, 2016).

Table 2

Influence of Electoral Uncertainty on Corporate Investment in Secondary Sector

\begin{tabular}{|c|c|c|c|c|c|c|c|c|c|}
\hline NFA & \multicolumn{3}{|c|}{ NACE $(\mathbf{C}-\mathbf{F})$} & \multicolumn{3}{|c|}{ NACE (C) } & \multicolumn{3}{|c|}{ NACE (F) } \\
\hline Size & $\begin{array}{l}8.3^{* * *} \\
(2.9)\end{array}$ & $\begin{array}{l}8.3^{* * * *} \\
(2.9)\end{array}$ & $\begin{array}{l}8.3^{* * *} \\
(2.9)\end{array}$ & $\begin{array}{c}12.6^{* *} \\
(2.8)\end{array}$ & $\begin{array}{c}12.6^{* *} \\
(2.8)\end{array}$ & $\begin{array}{l}12.6^{* *} \\
(2.8)\end{array}$ & $\begin{array}{l}1.55 \\
(0.4)\end{array}$ & $\begin{array}{r}1.55 \\
(0.4)\end{array}$ & $\begin{array}{l}1.55 \\
(0.4)\end{array}$ \\
\hline ROA & $\begin{array}{l}-0.02 \\
(-0.28)\end{array}$ & $\begin{array}{l}-0.02 \\
(-0.28)\end{array}$ & $\begin{array}{l}-0.02 \\
(-0.28)\end{array}$ & $\begin{array}{c}0.07 \\
(0.99) \\
\end{array}$ & $\begin{array}{l}0.07 \\
(0.99)\end{array}$ & $\begin{array}{c}0.07 \\
(0.99) \\
\end{array}$ & $\begin{array}{r}0.43 \\
(0.8)\end{array}$ & $\begin{array}{r}0.44 \\
(0.8) \\
\end{array}$ & $\begin{array}{r}0.44 \\
(0.8)\end{array}$ \\
\hline CashFlowAssets & $\begin{array}{c}0.19 \\
(0.57)\end{array}$ & $\begin{array}{c}0.19 \\
(0.57) \\
\end{array}$ & $\begin{array}{c}0.19 \\
(0.57) \\
\end{array}$ & $\begin{array}{c}16.95 \\
(0.5) \\
\end{array}$ & $\begin{array}{r}16.95 \\
(0.5) \\
\end{array}$ & $\begin{array}{c}16.95 \\
(0.5) \\
\end{array}$ & $\begin{array}{c}18.8 \\
(1.0)\end{array}$ & $\begin{array}{l}18.8 \\
(1.0)\end{array}$ & $\begin{array}{l}18.8 \\
(1.0)\end{array}$ \\
\hline ShortDebtRatio & $\begin{array}{l}16.8^{* * *} \\
(2.5)\end{array}$ & $\begin{array}{l}16.8^{* * *} \\
(2.5)\end{array}$ & $\begin{array}{l}16.8^{* *} \\
(2.5)\end{array}$ & $\begin{array}{c}28.9^{*} \\
(1.9)\end{array}$ & $\begin{array}{c}28.9^{*} \\
(1.9)\end{array}$ & $\begin{array}{r}28.9^{*} \\
(1.9)\end{array}$ & $\begin{array}{c}3.7^{* \ldots \times n} \\
(17.3)\end{array}$ & 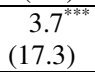 & $\begin{array}{c}3.7^{* * * *} \\
(17.3)\end{array}$ \\
\hline LongDebtRatio & \begin{tabular}{|l}
$-1.7^{*}$ \\
$(-1.7)$ \\
\end{tabular} & \begin{tabular}{|l}
$-1.7^{*}$ \\
$(-1.7)$ \\
\end{tabular} & \begin{tabular}{|l|}
$-1.7^{*}$ \\
$(-1.7)$ \\
\end{tabular} & $\begin{array}{r}6.68 \\
(1.7) \\
\end{array}$ & $\begin{array}{r}6.69 \\
(1.7) \\
\end{array}$ & $\begin{array}{r}6.68 \\
(1.7) \\
\end{array}$ & $\begin{array}{r}0.21 \\
(0.4) \\
\end{array}$ & $\begin{array}{r}0.21 \\
(0.4) \\
\end{array}$ & $\begin{array}{r}0.21 \\
(0.4) \\
\end{array}$ \\
\hline Liquidity & $\begin{array}{r}0.05 \\
(0.3) \\
\end{array}$ & $\begin{array}{r}0.04 \\
(0.3) \\
\end{array}$ & $\begin{array}{r}0.05 \\
(0.3) \\
\end{array}$ & $\begin{array}{c}0.28 \\
(0.7) \\
\end{array}$ & $\begin{array}{r}0.28 \\
(0.7) \\
\end{array}$ & $\begin{array}{r}0.28 \\
(0.7) \\
\end{array}$ & $\begin{array}{l}-0.2^{* * * *} \\
(-4.7) \\
\end{array}$ & $\begin{array}{l}-0.2^{* * * *} \\
(-4.7) \\
\end{array}$ & $\begin{array}{l}-0.2^{* * *} \\
(-4.7)\end{array}$ \\
\hline Growth (t-1) & $\begin{array}{l}-0.12 \\
(-1.1) \\
\end{array}$ & $\begin{array}{l}-0.1 \\
(-0.9) \\
\end{array}$ & \begin{tabular}{|l|}
-0.12 \\
$(-1.1)$ \\
\end{tabular} & $\begin{array}{l}-0.14 \\
(-1.1) \\
\end{array}$ & \begin{tabular}{|l|}
-0.1 \\
$(-0.8)$ \\
\end{tabular} & $\begin{array}{l}-0.13 \\
(-1.1) \\
\end{array}$ & $\begin{array}{l}-0.2^{* * *} \\
(-2.7) \\
\end{array}$ & $\begin{array}{l}-0.2^{* *} \\
(-2.5) \\
\end{array}$ & $\begin{array}{l}-0.2^{* *} \\
(-2.7)\end{array}$ \\
\hline Debt (t-1) & $\begin{array}{r}0.05 \\
(1.1)\end{array}$ & $\begin{array}{r}0.05 \\
(1.1)\end{array}$ & $\begin{array}{c}0.05 \\
(1.0)\end{array}$ & $\begin{array}{c}0.04 \\
(1.2)\end{array}$ & $\begin{array}{c}0.05 \\
(1.2)\end{array}$ & $\begin{array}{c}0.04 \\
(1.1)\end{array}$ & $\begin{array}{r}0.05 \\
(0.9)\end{array}$ & $\begin{array}{c}0.05 \\
(0.9)\end{array}$ & $\begin{array}{c}0.05 \\
(0.9)\end{array}$ \\
\hline Elect & $\begin{array}{l}-0.4^{*} \\
(-1.8)\end{array}$ & & $\begin{array}{l}-0.5^{* *} \\
(-2.5)\end{array}$ & $\begin{array}{l}-0.6 \\
(-1.7)\end{array}$ & & $\begin{array}{l}-0.7^{* *} \\
(-2.1)\end{array}$ & $\begin{array}{l}-0.3^{* * *} \\
(-2.6)\end{array}$ & & $\begin{array}{l}-0.3^{* * * *} \\
(-3.6)\end{array}$ \\
\hline ElectDate & & $\begin{array}{l}-0.2 \\
(-1.1)\end{array}$ & & & $\begin{array}{l}-0.4 \\
(-1.5)\end{array}$ & & & $\begin{array}{l}0.1 \\
(0.7) \\
\end{array}$ & \\
\hline PostElect & & & $\begin{array}{l}-0.5^{* * *} \\
(-3.4)\end{array}$ & & & $\begin{array}{l}-0.4^{* *} \\
(-2.6)\end{array}$ & & & $\begin{array}{l}-0.4^{* * *} \\
(-3.3)\end{array}$ \\
\hline $\begin{array}{l}\text { Adjusted } \mathrm{R}^{2} \\
\text { (within) }\end{array}$ & & & & & 0.49 & & & & \\
\hline Observations & & $2,236,62$ & & & $1,250,673$ & & & 897,83 & \\
\hline
\end{tabular}

Note: $*, * *$ and $* * *$ denote significance at $10 \%, 5 \%$ and $1 \%$ level; t-statistics are reported in parentheses; constant, firm and year fixed effects are not reported; all regression models include robust standard errors clustered by country.

Source: Own calculations based on data from Döring and Manow (2020), Eurostat (2019) and Van Dijk (2019).

The results from comparing individual industries show that electoral uncertainty can have a negative effect on the construction sector, while no influence was identified (electricity and water supply), nor was it statistically conclusive (manufacturing).

Electoral uncertainty is most evident in the construction industry. This is because public administration at all levels influences the performance of construction companies, from public procurement to strategic development plans to legislation and regulation (Eurostat, 2009; Hillebrandt, 2000). Additionally, the risk of change in an economic policy can lead to a reduction or the postponement 
of investment spending in the election year. In the case of the manufacturing industry, it is not possible to clearly determine whether electoral uncertainty has an effect. For this reason, the article rather inclined to empirical literature (e.g. Riem, 2016; Shelton and Falk, 2016), according to which there should be a negative influence.

The paper offers two explanations for the statistical insignificance in the case of electricity and water supply. First, there is an important number of large enterprises compared to other industries (Eurostat, 2009; 2017), which means that the effects of electoral uncertainty are significantly reduced (see the following section). Second, high capital intensity (Eurostat, 2009) should cause the industry to be more dependent on political uncertainty (An et al., 2016), but since there is a larger share of state-owned companies (European Commission, 2016), the effect is mitigated because these companies invest more in the election year (Li, Lin and Xu, 2020).

At the same time, electoral uncertainty has an impact across sectors (except for electricity and water supply) when the election year is connected with the post-electoral effect, which is in accordance with Julio and Yook (2012). On the other hand, electoral uncertainty expressed as the date of the election between the last three months of the current fiscal year and the nine months of the following fiscal year seems to be statistically insignificant.

\section{Electoral Uncertainty and Corporate Investment in SMEs and Large Enterprises}

In the second part of the empirical analysis, the different impacts of electoral uncertainty on corporate investment in SMEs and large enterprises are monitored. More specifically, the regression analysis contains about 225,500 SMEs and about 42,000 large enterprises. The results are presented firstly for SMEs (Table 3) and then for large enterprises (Table 4). The outputs for the water and electricity supply are stated in Table A2 (Appendix).

In the case of the control variables, the results for the SMEs are very similar to the previous results, which means that corporate investment is influenced by the size of the company, its short-term debt and probably by its long-term debt and business cycle (manufacturing and construction). In terms of electoral uncertainty, the investment expenditures are lower in the election year compared to non-electoral years both within the secondary sector and within the most important industries (manufacturing and construction). Also, a post-electoral effect can be identified (secondary sector and construction). As with the previous results, no effect was detected within the electricity and water supply industries. 
Thus, electoral uncertainty has a negative impact on SMEs in the secondary sector. It means that the level of the net fixed assets to total assets in an election year is about 0.5 lower compared to non-electoral years (at an average level of $25.14 \%$ ). In other words, the net fixed investment declines by about $1.9 \%$ in the election year.

T a ble 3

Influence of Electoral Uncertainty on Corporate Investment in SMEs

\begin{tabular}{|c|c|c|c|c|c|c|c|c|c|}
\hline NFA & \multicolumn{3}{|c|}{ NACE $(C-F)$} & \multicolumn{3}{|c|}{ NACE (C) } & \multicolumn{3}{|c|}{ NACE (F) } \\
\hline Size & $\begin{array}{l}6.3^{* * * *} \\
(3.1)\end{array}$ & $\begin{array}{l}6.33^{* * * *} \\
(3.1)\end{array}$ & $\begin{array}{l}6.3^{* * *} \\
(3.1)\end{array}$ & $\begin{array}{l}1.4 \\
(0.7)\end{array}$ & $\begin{array}{l}1.4 \\
(0.7)\end{array}$ & $\begin{array}{l}1.4 \\
(0.7)\end{array}$ & $\begin{array}{l}-0.05 \\
(-0.01)\end{array}$ & $\begin{array}{l}-0.05 \\
(-0.01)\end{array}$ & $\begin{array}{l}-0.05 \\
(-0.01)\end{array}$ \\
\hline ROA & $\begin{array}{l}-0.7 \\
(-0.5)\end{array}$ & $\begin{array}{l}-0.7 \\
(-0.5)\end{array}$ & $\begin{array}{l}-0.7 \\
(-0.5)\end{array}$ & $\begin{array}{l}50.2^{* *} \\
(2.6)\end{array}$ & $\begin{array}{l}50.2^{* * *} \\
(2.6)\end{array}$ & $\begin{array}{c}50.2^{* *} \\
(2.6)\end{array}$ & $\begin{array}{c}0.4 \\
(0.9)\end{array}$ & $\begin{array}{c}0.4 \\
(0.9)\end{array}$ & $\begin{array}{c}0.4 \\
(0.9)\end{array}$ \\
\hline CashFlowAssets & $\begin{array}{c}0.9 \\
(0.5) \\
\end{array}$ & $\begin{array}{c}0.9 \\
(0.5) \\
\end{array}$ & $\begin{array}{c}0.9 \\
(0.5) \\
\end{array}$ & $\begin{array}{l}119^{* * *} \\
(2.1)\end{array}$ & $\begin{array}{c}119^{* *} \\
(2.2) \\
\end{array}$ & $\begin{array}{c}119^{* *} \\
(2.2)\end{array}$ & $\begin{array}{c}24.1 \\
(1.1)\end{array}$ & \begin{tabular}{|c|}
24.1 \\
$(1.1)$ \\
\end{tabular} & $\begin{array}{c}24.1 \\
(1.1) \\
\end{array}$ \\
\hline ShortDebtRatio & $\begin{array}{l}16.6^{* *} \\
(2.5)\end{array}$ & $\begin{array}{l}16.6^{* * *} \\
(2.5)\end{array}$ & $\begin{array}{l}16.6^{* *} \\
(2.5)\end{array}$ & $\begin{array}{l}18.2^{*} \\
(1.9)\end{array}$ & $\begin{array}{l}18.2^{*} \\
(1.9)\end{array}$ & $\begin{array}{l}18.2^{*} \\
(1.9)\end{array}$ & $\begin{array}{l}4.1^{* * * *} \\
(3.0)\end{array}$ & $\begin{array}{l}4.1^{* * * *} \\
(3.0)\end{array}$ & $\begin{array}{l}4.1^{* * * *} \\
(3.0)\end{array}$ \\
\hline LongDebtRatio & $\begin{array}{c}3.4 \\
(1.2)\end{array}$ & $\begin{array}{c}3.4 \\
(1.2)\end{array}$ & $\begin{array}{c}3.4 \\
(1.2)\end{array}$ & $\begin{array}{c}16.7^{* * * *} \\
(3.1)\end{array}$ & $\begin{array}{l}16.7^{* * * *} \\
(3.1)\end{array}$ & $\begin{array}{l}16.7^{* * *} \\
(3.1)\end{array}$ & $\begin{array}{l}12.9^{*} \\
(1.9)\end{array}$ & $\begin{array}{c}12.9^{*} \\
(1.9)\end{array}$ & $\begin{array}{c}12.9^{*} \\
(1.9)\end{array}$ \\
\hline Liquidity & $\begin{array}{c}0.06 \\
(0.3)\end{array}$ & $\begin{array}{c}0.06 \\
(0.3)\end{array}$ & $\begin{array}{r}0.06 \\
(0.3)\end{array}$ & $\begin{array}{l}-0.2 \\
(-1.0)\end{array}$ & $\begin{array}{l}-0.2 \\
(-1.0)\end{array}$ & $\begin{array}{c}-0.2 \\
(-1.0)\end{array}$ & $\begin{array}{l}-0.2^{* * *} \\
(-3.1)\end{array}$ & $\begin{array}{l}-0.2^{* * *} \\
(-3.1)\end{array}$ & $\begin{array}{l}-0.2^{* * * *} \\
(-3.1)\end{array}$ \\
\hline Growth (t-1) & \begin{tabular}{|l|}
-0.1 \\
$(-0.9)$
\end{tabular} & $\begin{array}{l}-0.06 \\
(-0.6)\end{array}$ & $\begin{array}{l}-0.08 \\
(-0.9)\end{array}$ & $\begin{array}{l}-0.3^{* *} \\
(-2.3)\end{array}$ & $\begin{array}{l}-0.3^{* * *} \\
(-2.1)\end{array}$ & $\begin{array}{l}-0.3^{* *} \\
(-2.3)\end{array}$ & $\begin{array}{l}-0.2^{* * *} \\
(-2.2)\end{array}$ & $\begin{array}{l}-0.2^{*} \\
(-1.9)\end{array}$ & $\begin{array}{l}-0.2^{* *} \\
(-2.1)\end{array}$ \\
\hline Debt (t-1) & $\begin{array}{r}0.03 \\
(0.7) \\
\end{array}$ & $\begin{array}{r}0.03 \\
(0.7) \\
\end{array}$ & $\begin{array}{c}0.02 \\
(0.6) \\
\end{array}$ & $\begin{array}{l}-0.04 \\
(-1.2)\end{array}$ & $\begin{array}{r}-0.04 \\
(-1.2) \\
\end{array}$ & $\begin{array}{r}-0.04 \\
(-1.3) \\
\end{array}$ & $\begin{array}{r}0.01 \\
(0.3) \\
\end{array}$ & $\begin{array}{r}0.01 \\
(0.3) \\
\end{array}$ & $\begin{array}{c}0.01 \\
(0.2) \\
\end{array}$ \\
\hline Elect & $\begin{array}{l}-0.4^{* *} \\
(-2.2)\end{array}$ & & $\begin{array}{l}-0.5^{* * *} \\
(-2.9)\end{array}$ & $\begin{array}{l}-0.5^{* *} \\
(-2.4)\end{array}$ & $a$ & $\begin{array}{l}-0.6^{* * * *} \\
(-3.4)\end{array}$ & $\begin{array}{l}-0.2^{*} \\
(-2.0)\end{array}$ & & $\begin{array}{l}-0.3^{* *} \\
(-2.6)\end{array}$ \\
\hline ElectDate & & $\begin{array}{l}-0.2 \\
(-1.3)\end{array}$ & & & $\begin{array}{c}-0.1 \\
(-0.4)\end{array}$ & & & $\begin{array}{l}0.1 \\
(0.5)\end{array}$ & \\
\hline PostElect & & & $\begin{array}{l}-0.47^{* * *} \\
(-3.1)\end{array}$ & & & $\begin{array}{l}-0.4 \\
(-1.4)\end{array}$ & & & $\begin{array}{l}-0.4^{* *} \\
(-2.4)\end{array}$ \\
\hline $\begin{array}{l}\text { Adjusted } \mathrm{R}^{2} \\
\text { (within) }\end{array}$ & \multicolumn{3}{|c|}{0.28} & \multicolumn{3}{|c|}{0.66} & \multicolumn{3}{|c|}{0.32} \\
\hline Observations & \multicolumn{3}{|c|}{$1,898,649$} & \multicolumn{3}{|c|}{$1,107,398$} & \multicolumn{3}{|c|}{720,662} \\
\hline
\end{tabular}

Note: $*, * *$ and $* * *$ denote significance at $10 \%, 5 \%$ and $1 \%$ level; t-statistics are reported in parentheses; constant, firm and year fixed effects are not reported; all regression models include robust standard errors clustered by country.

Source: Own calculations based on data from Döring and Manow (2020), Eurostat (2019) and Van Dijk (2019).

The results are consistent with Amore and Minichilli (2018), Dejuán and Ghirelli (2018), Ghosal and Loungani (2000) and Kang, Lee and Ratti (2014). According to Drobetz et al. (2018) uncertainty distorts the fundamental relation between investment and cost of capital, which is reflected especially in SMEs because these companies have a weaker financial position (Dejuán and Ghirelli, 2018; Ghosal and Loungani, 2000), poorer access to information (Ghosal and Loungani, 2000; Koetse, Van der Vlist and de Groot, 2006), higher risk aversion (Dejuán and Ghirelli, 2018) and less opportunities to hedge against a risk (Koetse, Van der Vlist and de Groot, 2006) compared to large enterprises. The negative impact of electoral uncertainty can also be explained by the fact that SMEs have 
locally or geographically concentrated production, which increases their susceptibility to possible changes in economic policy (Amore and Minichilli, 2018; Jens, 2017).

When focusing on large companies, it can be understood that the output of regression analysis suggests that the influence of electoral uncertainty is rather statistically ambiguous (secondary sector, manufacturing and construction) or statistically insignificant (electricity and water supply), which is in accordance with Kang, Lee and Ratti (2014).

To summarise, the results indicate that electoral uncertainty has a higher influence on the net fixed investment in SMEs than in large companies. In addition to the already mentioned factors, large companies have the advantage of better access to external financing (Beck, Demirgüç-Kunt and Maksimovic, 2008) and a lower level of sunk costs (Ghosal and Loungani, 2000). The results may also be affected by the presence of state-owned enterprises that have higher investment expenditures in an election year, which distinguishes them from other large firms (Li, Lin and $\mathrm{Xu}, 2020)$.

Table 4

Influence of Electoral Uncertainty on Corporate Investment in Large Enterprises

\begin{tabular}{|c|c|c|c|c|c|c|c|c|c|}
\hline NFA & \multicolumn{3}{|c|}{ NACE $(C-F)$} & \multicolumn{3}{|c|}{ NACE (C) } & \multicolumn{3}{|c|}{ NACE (F) } \\
\hline Size & $\begin{array}{l}17.4^{* * * *} \\
(3.1)\end{array}$ & $\begin{array}{l}17.4^{* * *} \\
(3.1)\end{array}$ & $\begin{array}{l}17.4^{* * * *} \\
(3.1)\end{array}$ & $\begin{array}{l}30.1^{* * *} \\
(3.3)\end{array}$ & $\begin{array}{l}30.1^{* * * *} \\
(3.3)\end{array}$ & $\begin{array}{l}30.1^{* * *} \\
(3.3)\end{array}$ & $\begin{array}{l}3.5 \\
(1.4)\end{array}$ & $\begin{array}{l}3.5 \\
(1.4)\end{array}$ & $\begin{array}{l}3.5 \\
(1.4)\end{array}$ \\
\hline ROA & $\begin{array}{l}-0.01 \\
(-0.5)\end{array}$ & $\begin{array}{l}-0.01 \\
(-0.5)\end{array}$ & $\begin{array}{l}-0.01 \\
(-0.5)\end{array}$ & $\begin{array}{l}-0.02 \\
(-0.6)\end{array}$ & $\begin{array}{l}-0.02 \\
(-0.6)\end{array}$ & $\begin{array}{l}-0.02 \\
(-0.6)\end{array}$ & $\begin{array}{c}0.1 \\
(0.7)\end{array}$ & $\begin{array}{c}0.1 \\
(0.7)\end{array}$ & $\begin{array}{c}0.1 \\
(0.7)\end{array}$ \\
\hline CashFlowAssets & $\begin{array}{l}-6.7 \\
(-0.8)\end{array}$ & \begin{tabular}{|l|}
-6.7 \\
$(-0.8)$ \\
\end{tabular} & \begin{tabular}{|l|}
-6.7 \\
$(-0.8)$ \\
\end{tabular} & $\begin{array}{l}-10.1^{*} \\
(-1.8)\end{array}$ & $\begin{array}{l}-10.1^{*} \\
(-1.8)\end{array}$ & $\begin{array}{l}-10.1^{*} \\
(-1.8)\end{array}$ & $\begin{array}{c}-1.1^{* * *} \\
(-10.7)\end{array}$ & $\begin{array}{c}-1.1^{* * * *} \\
(-10.7)\end{array}$ & $\begin{array}{c}-1.1^{* * * *} \\
(-10.7)\end{array}$ \\
\hline ShortDebtRatio & $\begin{array}{l}17.7 \\
(1.1)\end{array}$ & $\begin{array}{l}17.7 \\
(1.1)\end{array}$ & $\begin{array}{l}17.7 \\
(1.1)\end{array}$ & $\begin{array}{l}35.4^{* * * *} \\
(3.1)\end{array}$ & $\begin{array}{l}35.4^{* * *} \\
(3.1)\end{array}$ & $\begin{array}{l}35.4^{* * *} \\
(3.1)\end{array}$ & $\begin{array}{c}-1.6^{* * *} \\
(-37.1)\end{array}$ & $\begin{array}{c}-1.6^{* * *} \\
(-37.1)\end{array}$ & $\begin{array}{c}-1.6^{* * * *} \\
(-37.1)\end{array}$ \\
\hline LongDebtRatio & $\begin{array}{l}-2.7 \\
(-1.3)\end{array}$ & $\begin{array}{l}-2.7 \\
(-1.3)\end{array}$ & $\begin{array}{l}-2.7 \\
(-1.3)\end{array}$ & $\begin{array}{l}8.3 \\
(0.7)\end{array}$ & $\begin{array}{c}8.3 \\
(0.7)\end{array}$ & $\begin{array}{c}8.3 \\
(0.7)\end{array}$ & $\begin{array}{c}0.4^{*} \\
(1.9)\end{array}$ & $\begin{array}{c}0.4^{*} \\
(1.9)\end{array}$ & $\begin{array}{c}0.4^{*} \\
(1.9)\end{array}$ \\
\hline Liquidity & $\begin{array}{c}0.04 \\
(0.1)\end{array}$ & $\begin{array}{c}0.04 \\
(0.1)\end{array}$ & $\begin{array}{c}0.04 \\
(0.1)\end{array}$ & $\begin{array}{c}0.3 \\
(1.0)\end{array}$ & $\begin{array}{c}0.3 \\
(1.0)\end{array}$ & $\begin{array}{c}0.3 \\
(1.0)\end{array}$ & $\begin{array}{l}-0.2^{* * * *} \\
(-4.1)\end{array}$ & $\begin{array}{l}-0.2^{* * * *} \\
(-4.1)\end{array}$ & $\begin{array}{l}-0.2^{* * * *} \\
(-4.1)\end{array}$ \\
\hline Growth (t-1) & $\begin{array}{l}-0.3^{* * *} \\
(-2.4)\end{array}$ & $\begin{array}{l}-0.3^{* * *} \\
(-2.5)\end{array}$ & $\begin{array}{l}-0.3^{* *} \\
(-2.5)\end{array}$ & $\begin{array}{l}-0.4^{* *} \\
(-2.3)\end{array}$ & $\begin{array}{l}-0.4^{* *} \\
(-2.2)\end{array}$ & $\begin{array}{l}-0.4^{* *} \\
(-2.4)\end{array}$ & $\begin{array}{l}-0.2^{* *} \\
(-2.4)\end{array}$ & $\begin{array}{l}-0.2^{* *} \\
(-2.4)\end{array}$ & $\begin{array}{l}-0.2^{* *} \\
(-2.4)\end{array}$ \\
\hline Debt $(t-1)$ & $\begin{array}{c}0.2^{*} \\
(1.9) \\
\end{array}$ & $\begin{array}{c}0.2^{*} \\
(1.9) \\
\end{array}$ & $\begin{array}{c}0.2^{*} \\
(1.9) \\
\end{array}$ & $\begin{array}{c}0.2^{*} \\
(1.8)\end{array}$ & $\begin{array}{c}0.2^{*} \\
(1.8)\end{array}$ & $\begin{array}{c}0.2^{*} \\
(1.8) \\
\end{array}$ & $\begin{array}{c}0.1 \\
(1.7) \\
\end{array}$ & $\begin{array}{c}0.1 \\
(1.7)\end{array}$ & $\begin{array}{c}0.1 \\
(1.7)\end{array}$ \\
\hline Elect & $\begin{array}{l}-0.1 \\
(-0.2)\end{array}$ & & $\begin{array}{l}-0.2 \\
(-0.5) \\
\end{array}$ & $\begin{array}{l}-0.5 \\
(-0.7) \\
\end{array}$ & & $\begin{array}{l}-0.6 \\
(-0.9) \\
\end{array}$ & $\begin{array}{l}-0.3 \\
(-1.1) \\
\end{array}$ & & $\begin{array}{l}-0.3 \\
(-1.3) \\
\end{array}$ \\
\hline ElectDate & & $\begin{array}{c}0.1 \\
(0.9) \\
\end{array}$ & & & $\begin{array}{l}-0.3^{*} \\
(-1.9)\end{array}$ & & & $\begin{array}{r}0.3 \\
(1.3) \\
\end{array}$ & \\
\hline PostElect & & & \begin{tabular}{|l}
$-0.6^{* *}$ \\
$(-2.1)$
\end{tabular} & & & $\begin{array}{l}-0.74^{*} \\
(-1.9) \\
\end{array}$ & & & $\begin{array}{l}-0.5^{* *} \\
(-2.7) \\
\end{array}$ \\
\hline $\begin{array}{l}\text { Adjusted } \mathrm{R}^{2} \\
\text { (within) }\end{array}$ & \multicolumn{3}{|c|}{0.31} & \multicolumn{3}{|c|}{0.66} & \multicolumn{3}{|c|}{0.05} \\
\hline Observations & \multicolumn{3}{|c|}{337,413} & \multicolumn{3}{|c|}{143,129} & \multicolumn{3}{|c|}{176,982} \\
\hline
\end{tabular}

Note: $* * *$ and $* * *$ denote significance at $10 \%, 5 \%$ and $1 \%$ level; t-statistics are reported in parentheses; constant, firm and year fixed effects are not reported; all regression models include robust standard errors clustered by country.

Source: Own calculations based on data from Döring and Manow (2020), Eurostat (2019) and Van Dijk (2019). 


\section{Conclusions}

The aim of the paper was to identify whether electoral uncertainty affects corporate investment in European countries. More specifically, the paper focused on net fixed-asset investment in the secondary sector (NACE Rev. 2 Sections C - F). Electoral uncertainty was associated with the parliamentary election term since it is the most common election type within EU countries. As the basic research question, it was assumed that a decline in corporate investment is expected in the election year. The election uncertainty was expressed by three variables, Elect (1 for election year; the most frequent expression in empirical literature), ElectDate ( 1 if the election date is between 90 days prior to the end of the fiscal year $t$ and 274 days after the end of the fiscal year t; Julio and Yook, 2012) and PostElect ( 1 if the election date lies between 274 days before the beginning of the fiscal year $\mathrm{t}$ and 90 days after the beginning of the fiscal year $\mathrm{t}$; Julio and Yook, 2012).

Seven countries out of the twenty-eight EU member states were not included in the analysis (namely Cyprus, Denmark, Latvia, Lithuania, Luxembourg, Malta and the Netherlands) because of a shortage of suitable firm data. In total, the paper employed data for about 268,000 firms. The influence of electoral uncertainty was investigated and focused on the period between 2006 and 2015 using an OLS fixed effects estimator. The different impacts of electoral uncertainty were also explored in SMEs and large companies.

The results for the election proxies indicate that the negative effect of holding the parliamentary elections on corporate investment in the secondary sector can be statistically significant. A closer look reveals that the negative effects may be manifested in the election year, and there may also be post-electoral influence. This means that the level of net fixed assets to total assets in the election year is about 0.4 lower compared to non-electoral years (at an average level of $26.17 \%$ ). In other words, a net fixed investment declines by about $1.9 \%$ in an election year. The results from comparing the individual industries show that electoral uncertainty can have a negative effect on the construction sector, while no influence was identified (electricity and water supply), nor was it statistically conclusive (manufacturing). Additionally, electoral uncertainty has an impact across sectors (except for electricity and water supply) when the election year relates to the post-electoral effect.

In the second part of the empirical analysis, the different impacts of electoral uncertainty on corporate investment in SMEs and large enterprises were monitored. More specifically, investment expenditures are lower in the election year compared to non-electoral years within the secondary sector and within the most important industries (manufacturing and construction). Also, a post-electoral 
effect can be identified (secondary sector and construction). Thus, electoral uncertainty has a negative impact on SMEs in the secondary sector. This means that the level of net fixed assets to total assets in an election year is about 0.5 lower compared to non-electoral years (at average level 25.14\%). In other words, the net fixed-asset investment declines by about $1.9 \%$ in an election year. The focus on large companies shows that the output of regression analysis suggests that the influence of electoral uncertainty is rather statistically ambiguous (secondary sector, manufacturing and construction) or statistically insignificant (electricity and water supply). To summarise, the article comes to similar conclusions as the empirical literature, namely that electoral uncertainty has a negative impact on an investment (Jens, 2017; Julio and Yook, 2012; Marcelin et al., 2019; Narayan, Narayan and Tran, 2017; Riem, 2016) and more on SMEs (Amore and Minichilli, 2018; Dejuán and Ghirelli, 2018; Ghosal and Loungani, 2000; Kang, Lee and Ratti, 2014). The main benefit compared to the mentioned articles is that the impacts of electoral uncertainty are compared across the selected sectors (manufacturing, electricity and water supply, construction).

Finally, it should be noted that the findings include several research limitations. The observed effects are analysed on a relatively short time series (10 years), and, simultaneously, the period was strongly influenced by the economic crisis, whose influence was only filtered out by two selected control variables (development of real GDP and size of government debt). Using many companies on one hand increased the number of observations, but on the other hand it does not enable the ability to work with Tobin's Q, which is the fundamental control variable in the empirical literature.

As a possible extension of the research, the paper proposes five options. First, the issue of elections should be extended to include additional electoral characteristics (e.g. regular and early elections; regional and state elections). Second, the conditional political factors should be considered, for example the characteristics of a political (parliamentary or presidential democracy; closeness of electoral outcomes; polarisation) and institutional (checks and balances; political stability, government effectiveness, rule of law, corruption) environment. Third, the secondary sector offers only limited possibilities for the generalisation of results, so it would be appropriate to add other important divisions of the tertiary sector (e.g., transportation and storage, information and communication, financial and insurance activities). Fourth is to put more emphasis on the differentiation of the various kinds of corporate investment (e.g. intangible assets, planned and unplanned investment spending), at microeconomic and macroeconomic levels. Last, the article focuses on the European space, and adding an analysis at the national level seems to be appropriate. 


\section{References}

AMORE, M. D. - MINICHILLI, A. (2018): Local Political Uncertainty, Family Control, and Investment Behavior. Journal of Financial and Quantitative Analysis, 53, No. 4, pp. 1781 - 1804. Available at: 〈https://doi.org/10.1017/S002210901800025X〉.

AN, H. - CHEN, Y. - LUO, D. - ZHANG, T. (2016): Political Uncertainty and Corporate Investment: Evidence from China. Journal of Corporate Finance, 36, pp. 174 - 189. Available at: <https://doi.org/10.1016/j.jcorpfin.2015.11.003>.

AROURI, M. - ESTAY, C. - RAULT, C. - ROUBAUD, D. (2016): Economic Policy Uncertainty and Stock Markets: Long-run Evidence from the US. Finance Research Letters, 18, pp. 136 - 141. Available at: 〈https://doi.org/10.1016/j.frl.2016.04.011>.

BECK, T. - DEMIRGÜÇ-KUNT, A. - MAKSIMOVIC, V. (2008): Financing Patterns around the World: Are Small Firms Different? Journal of Financial Economics, 89, No. 3, pp. 467 - 487. Available at: <https://doi.org/10.1016/j.jfineco.2007.10.005>.

BERNANKE, B. S. (1983): Irreversibility, Uncertainty, and Cyclical Investment. The Quarterly Journal of Economics, 98, No. 1, pp. 85 - 106. Available at: <https://doi.org/10.2307/1885568>.

BLOOM, N. - BOND, S. - VAN REENEN, J. (2007): Uncertainty and Investment Dynamics. The Review of Economic Studies, 74, No. 2, pp. $391-415$. Available at: <https://doi.org/10.1111/j.1467-937X.2007.00426.x>.

CARRUTH, A. - DICKERSON, A. - HENLEY, A. (2000): What Do We Know about Investment under Uncertainty? Journal of Economic Surveys, 14, No. 2, pp. 119 - 154. Available at: <https://doi.org/10.1111/1467-6419.00107>.

DEJUÁN, D. - GHIRELLI, C. (2018): Policy Uncertainty and Investment in Spain. [Working Paper, No. 1848.] Madrid: Banco de Espana [Cit. 18. 05. 2021.] Available at: <http://dx.doi.org/10.2139/ssrn.3306560>.

DÖRING, H. - MANOW, P. (2020): Parliaments and Governments Database. Parlgov: Information on Parties, Elections and Cabinets in Modern Democracies. [Cit. 18. 05. 2021.] Available at: $<\mathrm{http} / / / \mathrm{www}$.parlgov.org>.

DROBETZ, W. - EL GHOUL, S. - GUEDHAMI, O. - JANZEN, M. (2018): Policy Uncertainty, Investment, and the Cost of Capital. Journal of Financial Stability, 39, pp. 28 - 45. Available at: <https://doi.org/10.1016/j.jfs.2018.08.005>.

EUROPEAN COMMISSION (2016): State-Owned Enterprises in the EU: Lessons Learnt and Ways Forward in a Post-Crisis Context. [European Economy Institutional Paper 31.] Luxembourg: European Communities. [Cit. 18. 05. 2021.] Available at: <https://doi.org/10.2765/99224>.

EUROSTAT (2009): European Business: Facts and Figures - 2009 Edition. Luxembourg: European Communities. ISBN 978-92-79-12407-5. Available at: <https://doi.org/10.2785/23246>.

EUROSTAT (2017): Business Economy by Sector - NACE Rev. 2. Luxembourg: European Communities. [Cit. 18. 05. 2021.] Available at: <https://ec.europa.eu/eurostat/statistics-explained/ index.php/Business_economy_by_sector_-_NACE_Rev._2>.

EUROSTAT (2019): Economy and Finance. Luxembourg: European Communities. [Cit. 18. 05. 2021.] Available at: <https://ec.europa.eu/eurostat/data/database>.

GHOSAL, V. - LOUNGANI, P. (2000): The Differential Impact of Uncertainty on Investment in Small and Large Businesses. The Review of Economics and Statistics, 82, No. 2, pp. 338 - 343. Available at: 〈https://doi.org/10.1162/003465300558722>.

GULEN, H. - ION, M. (2015): Policy Uncertainty and Corporate Investment. The Review of Financial Studies, 29, No. 3, pp. 523 - 564. Available at: <https://doi.org/10.1093/rfs/hhv050>.

HIGGS, R. (1997): Regime Uncertainty: Why the Great Depression Lasted so Long and Why Prosperity Resumed after the War. The Independent Review, 1, No. 4, pp. 561 - 590.

HILLEBRANDT, P. M. (2000): Economic Theory and the Construction Industry. London: Macmillan. ISBN 978-0-230-37248-1. Available at: <https://doi.org/10.1057/9780230372481>. 
HOECHLE, D. (2007): Robust standard Errors for Panel Regressions with Cross-Sectional Dependence. The Stata Journal, 7, No. 3, pp. 281 - 312. Available at: <ttps://doi.org/10.1177/1536867X0700700301>.

JENS, C. E. (2017): Political Uncertainty and Investment: Causal Evidence from US Gubernatorial Elections. Journal of Financial Economics, 124, No. 3, pp. 563 - 579. Available at: <https://doi.org/10.1016/j.jfineco.2016.01.034>.

JULIO, B. - YOOK, Y. (2012): Political Uncertainty and Corporate Investment Cycles. The Journal of Finance, 67, No. 1, pp. $45-83$. Available at: <https://doi.org/10.1111/j.1540-6261.2011.01707.x>.

KAJUROVÁ, V. - LINNERTOVÁ, D. (2018): Loose Monetary Policy and Corporate Investment of Manufacturing Firms in the Czech Republic. Review of Economic Perspectives, 18, No. 4, pp. 371 - 385. Available at: 〈https://doi.org/10.2478/revecp-2018-0019>.

KANG, W. - LEE, K. - RATTI, R. A. (2014): Economic Policy Uncertainty and Firm-level Investment. Journal of Macroeconomics, 39, pp. 42 - 53. Available at: <https://doi.org/10.1016/j.jmacro.2013.10.006>.

KANG, W. - RATTI, R. A. (2013): Oil Shocks, Policy Uncertainty and Stock Market Return. Journal of International Financial Markets, Institutions and Money, 26, No. 1, pp. $305-318$. Available at: <https://doi.org/10.1016/j.intfin.2013.07.001>.

KOETSE, M. J. - DE GROOT, H. L. - FLORAX, R. J. (2009): A Meta-analysis of the Investmentuncertainty Relationship. Southern Economic Journal, 76, No. 1, pp. 283 - 306. Available at: <https://doi.org/10.4284/sej.2009.76.1.283>.

KOETSE, M. J. - VAN DER VLIST, A. J. - DE GROOT, H. L. (2006): The Impact of Perceived Expectations and Uncertainty on Firm Investment. Small Business Economics, 26, No. 4, pp. 365 - 376. Available at: 〈https://doi.org/10.1007/s11187-005-3201-3〉.

KOLEV, A. - BRUTSCHER, P. - WEISS, C. (2016): Investment and Investment Finance in Europe: Financing Productivity Growth. [EIB Annual Report on Investment and Investment Finance 2016.] Luxembourg: EIB [Cit. 18. 05. 2021.] Available at: <https://www.eib.org/ attachments/efs/investment_and_investment_finance_in_europe_2016_en.pdf >.

LI, Q. - LIN, C. - XU, L. (2020): Political Investment Cycles of State-owned Enterprises. The Review of Financial Studies, 33, No. 7, pp. 3088 - 3129. Available at: <https://doi.org/10.1093/rfs/hhz090>.

LIU, L. - ZHANG, T. (2015): Economic Policy Uncertainty and Stock Market Volatility. Finance Research Letters, 15, pp. 99 - 105. Available at: 〈https://doi.org/10.1016/j.frl.2015.08.009>.

MARCELIN, I. - STEPHEN, S. A. K. - FANTA, F. - TECKLEZION, M. (2019): Political Regimes, Investment and Electoral Uncertainty. Research in International Business and Finance, 47, pp. 580 - 599. Available at: 〈https://doi.org/10.1016/j.ribaf.2018.10.003〉.

MUNTAZ, H. - SURICO, P. (2018): Policy Uncertainty and Aggregate Fluctuations. Journal of Applied Econometrics, 33, No. 3, pp. 319 - 331. Available at: <https://doi.org/10.1002/jae.2613>.

NARAYAN, P. K. - NARAYAN, S. - TRAN, V. T. (2017): Political Uncertainty and Corporate Investment: State-level Evidence from Australia. [SSRN 2907584.] [Cit. 18. 05. 2021.] Rochester: SSRN. Available at: <http://dx.doi.org/10.2139/ssrn.2907584>.

NICKELL, S. (1981): Biases in Dynamic Models with Fixed Effects. Econometrica, 49, No. 6, pp. 1417 - 1426. Available at: 〈https://doi.org/10.2307/1911408>.

PETERSEN, M. A. (2009): Estimating Standard Errors in Finance Panel Data Sets: Comparing Approaches. The Review of Financial Studies, 22, No. 1, pp. 435 - 480. Available at: <https://doi.org/10.1093/rfs/hhn053>.

PINDYCK, R. S. (1991): Irreversibility, Uncertainty, and Investment. Journal of Economic Literature, 29, No. 3, pp. $1110-1148$.

RIEM, M. (2016): Corporate Investment Decisions under Political Uncertainty. [ifo Working Paper, No. 221.] Munich: ifo Institut. [Cit. 18. 05. 2021.] Available at: <https://www.ifo.de/DocDL/wp-2016-221-riem-corporate-investment-decisions.pdf〉. 
SHELTON, C. A. - FALK, N. (2016): Policy Uncertainty and Manufacturing Investment: Evidence from US State Elections. [CESifo Working Paper, No. 5846.] Munich: CESifo. [Cit. 18. 05. 2021.] Available at: 〈https://www.cesifo.org/DocDL/cesifo1_wp5846.pdf〉.

STOKEY, N. L. (2016): Wait-and-see: Investment Options under Policy Uncertainty. Review of Economic Dynamics, 21, pp. 246 - 265. Available at:

<https://doi.org/10.1016/j.red.2015.06.001>.

VAN DIJK, B. (2019): Amadeus Database. Last Data Update: 18/01/2017. [Cit. 18. 05. 2021.] Available at: 〈https://www.bvdinfo.com/en-gb/our-products/data/international/amadeus >.

\section{Appendix}

T able A1

Description of Variables

\begin{tabular}{|c|c|c|}
\hline Variable & Description & Source \\
\hline \multicolumn{3}{|c|}{ Dependent variable } \\
\hline NFA & Share of net fixed assets (FIAS minus DEPR) in total assets (TOAS) & Van Dijk (2019) \\
\hline \multicolumn{3}{|c|}{ Firm-level control proxies } \\
\hline $\begin{array}{l}\text { Size } \\
\text { ROA } \\
\text { ShortDebtRatio } \\
\text { LongDebtRatio } \\
\text { CashFlowAssets } \\
\text { Liquidity }\end{array}$ & $\begin{array}{l}\text { Natural logarithm of total assets (TOAS) } \\
\text { Share of EBIT (OPPL) in total assets (TOAS) } \\
\text { Share of current liabilities (CULI) in total assets (TOAS) } \\
\text { Share of long-term liabilities (LTDB) in total assets (TOAS) } \\
\text { Share of cash flow (CF) in total assets (TOAS) } \\
\text { Current assets (CUAS) minus inventories (STOK) divided current } \\
\text { liabilities (CULI) }\end{array}$ & Van Dijk (2019) \\
\hline \multicolumn{3}{|c|}{ Macroeconomic control proxies } \\
\hline $\begin{array}{l}\text { Growth }(\mathrm{t}-1) \\
\text { Debt }(\mathrm{t}-1)\end{array}$ & $\begin{array}{l}\text { The percentage change in the real GDP per capita in the previous year } \\
\text { Government consolidated gross debt to GDP }\end{array}$ & Eurostat (2019) \\
\hline \multicolumn{3}{|c|}{ Electoral uncertainty proxies } \\
\hline $\begin{array}{l}\text { Elect } \\
\text { ElectDate }\end{array}$ & $\begin{array}{l}\text { Dummy variable coded } 1 \text { for year in which the elections take place } \\
\text { Dummy variable code } 1 \text { if the date of the election lies between } \\
90 \text { days prior to the end of the fiscal year } t \text { and } 274 \text { days after the end } \\
\text { of the fiscal year } t \\
\text { Dummy variable code } 1 \text { if the date of the election lies between } \\
274 \text { days before the beginning of the fiscal year } t \text { and } 90 \text { days after } \\
\text { the beginning of the fiscal year } t\end{array}$ & $\begin{array}{l}\text { Döring and } \\
\text { Manow (2020) }\end{array}$ \\
\hline
\end{tabular}

Note: The BvD Code is stated in parentheses. 
Table A2

Influence of Electoral Uncertainty on Corporate Investment in Electricity and Water Supply Industries

\begin{tabular}{|c|c|c|c|c|c|c|c|c|c|}
\hline NFA & \multicolumn{3}{|c|}{ NACE $(D-E)$} & \multicolumn{3}{|c|}{ SMES } & \multicolumn{3}{|c|}{ Large enterprises } \\
\hline Size & $\begin{array}{l}6.6^{* * *} \\
(8.0)\end{array}$ & $\begin{array}{l}6.6^{* * *} \\
(8.0)\end{array}$ & $\begin{array}{l}6.6^{* * *} \\
(8.0)\end{array}$ & $\begin{array}{l}5.8^{* * * *} \\
(6.5)\end{array}$ & $\begin{array}{l}5.8^{* * *} \\
(6.5)\end{array}$ & $\begin{array}{l}5.8^{* * *} \\
(6.5)\end{array}$ & $\begin{array}{l}5.5^{* *} \\
(2.7)\end{array}$ & $\begin{array}{l}5.5^{* *} \\
(2.7)\end{array}$ & $\begin{array}{l}5.5^{* *} \\
(2.7)\end{array}$ \\
\hline ROA & $\begin{array}{l}5.2 \\
(0.9)\end{array}$ & $\begin{array}{l}5.2 \\
(0.9) \\
\end{array}$ & $\begin{array}{c}5.2 \\
(0.9)\end{array}$ & $\begin{array}{c}0.6 \\
(1.1)\end{array}$ & $\begin{array}{c}0.6 \\
(1.1)\end{array}$ & $\begin{array}{c}0.6 \\
(1.1)\end{array}$ & $\begin{array}{l}62.8^{* * *} \\
(2.2)\end{array}$ & $\begin{array}{l}62.8^{* *} \\
(2.2)\end{array}$ & $\begin{array}{l}62.8^{* *} \\
(2.2)\end{array}$ \\
\hline CashFlowAssets & $\begin{array}{l}-5.2 \\
(-0.9)\end{array}$ & $\begin{array}{l}-5.2 \\
(-0.9)\end{array}$ & $\begin{array}{l}-5.2 \\
(-0.9)\end{array}$ & $\begin{array}{l}-0.6 \\
(-1.1)\end{array}$ & $\begin{array}{l}-0.6 \\
(-1.1)\end{array}$ & $\begin{array}{l}-0.6 \\
(-1.1)\end{array}$ & $\begin{array}{c}-65.1^{* * *} \\
(-2.2)\end{array}$ & $\begin{array}{c}-65.1^{* *} \\
(-2.2)\end{array}$ & $\begin{array}{c}-65.1^{* *} \\
(-2.2)\end{array}$ \\
\hline ShortDebtRatio & $\begin{array}{l}-2.5^{*} \\
(-1.9)\end{array}$ & $\begin{array}{l}-2.5^{*} \\
(-1.9)\end{array}$ & $\begin{array}{l}-2.5^{*} \\
(-1.9)\end{array}$ & $\begin{array}{l}-1.0 \\
(-1.4)\end{array}$ & $\begin{array}{l}-1.0 \\
(-1.4)\end{array}$ & $\begin{array}{l}-1.0 \\
(-1.4)\end{array}$ & \begin{tabular}{|c|}
2.7 \\
$(0.8)$
\end{tabular} & $\begin{array}{l}2.7 \\
(0.8)\end{array}$ & $\begin{array}{l}2.7 \\
(0.8)\end{array}$ \\
\hline LongDebtRatio & $\begin{array}{l}3.5 \\
(1.7) \\
\end{array}$ & $\begin{array}{l}3.5 \\
(1.7) \\
\end{array}$ & $\begin{array}{c}3.5 \\
(1.7) \\
\end{array}$ & $\begin{array}{l}3.7 \\
(1.6) \\
\end{array}$ & $\begin{array}{l}3.7 \\
(1.6) \\
\end{array}$ & $\begin{array}{c}3.7 \\
(1.6) \\
\end{array}$ & $\begin{array}{l}8.5^{* *} \\
(2.5) \\
\end{array}$ & $\begin{array}{l}8.5^{* *} \\
(2.5) \\
\end{array}$ & $\begin{array}{l}8.5^{* *} \\
(2.5) \\
\end{array}$ \\
\hline Liquidity & \begin{tabular}{|l}
$-0.5^{\text {k** }}$ \\
$(-13.6)$
\end{tabular} & $\begin{array}{c}-0.5^{* * * 6} \\
(-13.6)\end{array}$ & \begin{tabular}{|c}
$-0.5^{* * * *}$ \\
$(-13.6)$
\end{tabular} & $\begin{array}{c}-0.5^{* * * *} \\
(-10.9)\end{array}$ & $\begin{array}{c}-0.5^{* * *} \\
(-10.9)\end{array}$ & $\begin{array}{c}-0.5^{* * *} \\
(-10.9)\end{array}$ & $\begin{array}{l}-0.4^{* * * *} \\
(-9.7)\end{array}$ & $\begin{array}{l}-0.4^{* *+6} \\
(-9.7)\end{array}$ & $\begin{array}{l}-0.4^{* *} \\
(-9.7)\end{array}$ \\
\hline Growth (t-1) & $\begin{array}{l}-0.01 \\
(-0.0)\end{array}$ & $\begin{array}{l}-0.01 \\
(-0.0)\end{array}$ & $\begin{array}{l}-0.01 \\
(-0.0)\end{array}$ & $\begin{array}{l}-0.04 \\
(-0.6)\end{array}$ & $\begin{array}{l}-0.04 \\
(-0.6)\end{array}$ & $\begin{array}{l}-0.04 \\
(-0.6)\end{array}$ & $\begin{array}{l}0.2^{* *} \\
(2.2)\end{array}$ & $\begin{array}{l}0.2^{* *} \\
(2.2)\end{array}$ & $\begin{array}{l}0.2^{* *} \\
(2.2)\end{array}$ \\
\hline Debt (t-1) & $\begin{array}{l}-0.01 \\
(-0.2)\end{array}$ & $\begin{array}{l}-0.01 \\
(-0.2)\end{array}$ & $\begin{array}{l}-0.01 \\
(-0.2)\end{array}$ & $\begin{array}{l}-0.03 \\
(-1.2)\end{array}$ & $\begin{array}{l}-0.03 \\
(-1.2)\end{array}$ & $\begin{array}{l}-0.03 \\
(-1.2)\end{array}$ & $\begin{array}{r}0.07 \\
(1.4)\end{array}$ & $\begin{array}{r}0.07 \\
(1.4)\end{array}$ & $\begin{array}{r}0.07 \\
(1.4)\end{array}$ \\
\hline Elect & $\begin{array}{l}-0.2 \\
(-1.0)\end{array}$ & & $\begin{array}{l}-0.2 \\
(-1.5)\end{array}$ & $\begin{array}{l}-0.2 \\
(-1.4)\end{array}$ & & $\begin{array}{l}-0.3 \\
(-1.6)\end{array}$ & $\begin{array}{c}0.3 \\
(1.2)\end{array}$ & & $\begin{array}{c}0.3 \\
(1.1)\end{array}$ \\
\hline ElectDate & & $\begin{array}{l}-0.1 \\
(-1.1) \\
\end{array}$ & & & $\begin{array}{l}-0.2 \\
(-1.6)\end{array}$ & & & $\begin{array}{l}-0.3 \\
(-1.2) \\
\end{array}$ & \\
\hline PostElect & & & $\begin{array}{l}-0.2^{* *} \\
(-2.1)\end{array}$ & & & $\begin{array}{l}-0.3 \\
(-1.6)\end{array}$ & & & $\begin{array}{l}-0.3 \\
(-1.1)\end{array}$ \\
\hline $\begin{array}{l}\text { Adjusted } \mathrm{R}^{2} \\
\text { (within) }\end{array}$ & \multicolumn{3}{|c|}{0.07} & \multicolumn{3}{|c|}{0.07} & \multicolumn{3}{|c|}{0.59} \\
\hline Observations & \multicolumn{3}{|c|}{88,114} & \multicolumn{3}{|c|}{70,589} & \multicolumn{3}{|c|}{17,302} \\
\hline
\end{tabular}

Note: $*, * *$ and $* * *$ denote significance at $10 \%, 5 \%$ and $1 \%$ level; t-statistics are reported in parentheses; constant, firm and year fixed effects are not reported; all regression models include robust standard errors clustered by country.

Source: Own calculations based on data from Döring and Manow (2020), Eurostat (2019) and Van Dijk (2019). 